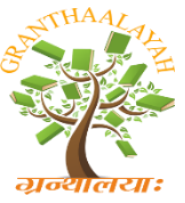

$$
\begin{gathered}
\text { INTERNATIONAL JOURNAL OF RESEARCH - } \\
\text { GRANTHAALAYAH } \\
\text { A knowledge Repository }
\end{gathered}
$$

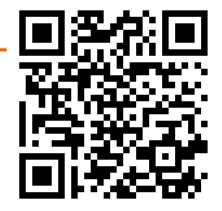

Science

\title{
EVALUATION OF DEHYDRATED MUKIA MADERASPATANA LEAVES AS A POTENT SOURCE OF DIETARY ANTIOXIDANTS
}

\author{
D. Amirtham ${ }^{*}$, J. Aswini Nivedida ${ }^{2}$, K. Dhivya ${ }^{3}$, S. Ganapathy ${ }^{4}$, C. Indurani ${ }^{5}$ \\ *1, 2, 3, 4, 5 Department of Food Agricultural Process Engineering, Tamil Nadu Agricultural \\ University, Coimbatore, India
}

\begin{abstract}
Green leafy vegetables are the most underexploited class of vegetables despite high nutritional value. The current study has been focused on the evaluation of anti-oxidant status of fresh and dehydrated under- utilized green leafy vegetable namely Mukia maderaspatana (L.) (Family: Cucurbitaceae), an indigenous plant; traditionally it is used as an ingredient of various cocktail preparations for the management of severe inflammatory disorders in Indian system of medicine. The total phenolic content (TPC), total flavonoid content (TFC) and total antioxidant activities were evaluated for the ethanolic extract of leaves to assess the in vitro antioxidant activities. The results showed that there exist a linear correlation between polyphenol content and antioxidant property. The ethanolic extract of dehydrated Mukia leaves showed the highest phenolic content (269.34 $\pm 0.78 \mathrm{mg} \mathrm{GAE} / \mathrm{g})$, and total antioxidant activity $(543 \pm 46 \mu \mathrm{mol}$ Trolox/100 g). HPTLC analysis has revealed the presence of significant quantity of Quercitin (26.52\%), an important flavonoid of tremendous antioxidant, anticancer and ant inflammatory properties in both the fresh and dehydrated leaves which might be the chief bioactive principle in Mukia.
\end{abstract}

Keywords: Underutilized Leaves; Mukia Maderaspatana; Antioxidants; Quercitin; HPTLC.

Cite This Article: D. Amirtham, J. Aswini Nivedida, K. Dhivya, S. Ganapathy, and C. Indurani. (2019). "EVALUATION OF DEHYDRATED MUKIA MADERASPATANA LEAVES AS A POTENT SOURCE OF DIETARY ANTIOXIDANTS." International Journal of Research Granthaalayah, 7(6), 27-36. https://doi.org/10.29121/granthaalayah.v7.i6.2019.735.

\section{Introduction}

Green leafy vegetables constitute a major part of any balanced diet and are good sources of minerals and vitamins. Leafy and green vegetables are most commonly consumed and are accessible throughout the year in India and other parts of the world. Diversification of production and consumption habits to include a broader range of plant species, in particular those currently identified as 'underutilized', can contribute significantly to improve health and nutrition, livelihoods, household food security and ecological sustainability (Oselebe et al., 2013). 
The synthetic antioxidants (Butylated hydroxytoluene and Butylated hydroxyanisole) which are commonly used in processed foods have been reported to contain certain side effects such as hepatotoxicity and carcinogenesis (Wichi, 1988). Therefore, potential sources of natural antioxidant compounds have been searched in several types of plant materials such as vegetables, fruits, leaves, oilseeds, cereal crops, barks and roots (Ramarathnam et al., 1997). The ethnobotanical reports offer information on the medicinal properties of green leafy vegetables which include details on their antioxidant,antidiabetic (Kesari, Gupta, \& Watal, 2005), anticarcinogenic (Khanna, Rizvi, \& Chander, 2002), and antibacterial activities .These beneficial effects of green leafy vegetables are attributed, at least in part to, antioxidants.

Reports on nutritional composition some of the fresh leaves are available but the dehydrated leaves apparently have not been studied. Acceptability of fresh and processed products differs from one consumer to another but there is no doubt that they want nutritious and convenient food in the present fast moving society. Vegetables occupy an important position in the Indian diet but even $12 \%$ of the total world's production of vegetables is not enough to meet this country's requirements. Beside post harvest loss reduction, improved processing and storage of processed products can play a significant role in availability of these products.

One of the such underutilized greeny leafy vegetable Mukia maderaspatana (family: Cucurbitaceae), is a medicinal plant. The plant was reported to have activities such as hepatoprotective (Thabrew, etal., 1995), antirheumatic (Ramakrishnamacharya, C.H et al., 1996), diuretic, stomachic (a digestive tonic), gentle aperients, antipyretic and antiflatulent, antiasthmatic, anti-inflammatory, antidiabetic and antibronchitis and is used for tooth-ache besides its use in vertigo and biliousness (Chopra, R.N., 2002; Kirthikar,K.R and Basu, B.D., 1980). Most valuable Phytochemicals are the product secondary metabolism and possess chemical or structural complexity (Kunkel,G., 1984). The use of this herb has been reported in Indian Traditional Systems of Medicine and its modern applications are receiving wide spread attention day by day.

Hence, the present investigation was carried out to evaluate the antioxidant status and determine the possible chemical components from fresh and dehydrated Mukia maderaspatana (L.) leave by HPTLC.

\section{Materials and Methods}

\section{Collection and identification of plant material}

Leaves of the plant were collected from local region and District of Coimbatore, Tamil Nadu, India. The botanical identity was confirmed by a Botanical survey of India, Southern chapter, Coimbatore. 


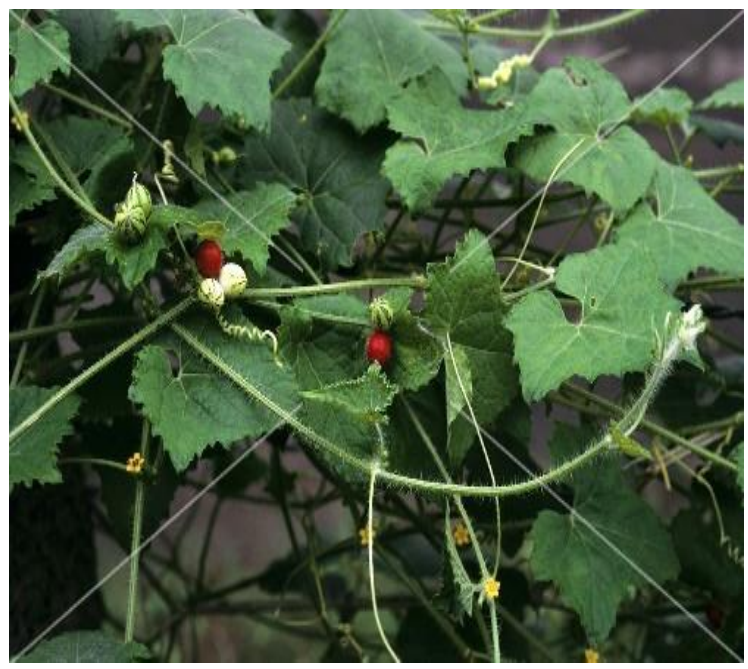

Figure 1: Fresh Mukia leaves

\section{Preparation of plant extracts}

The cabinet dried $\left(60^{\circ} \mathrm{C}\right)$ ground samples of Mukia maderaspatana (MME) and were defatted with petroleum ether for $24 \mathrm{~h}$, air dried and extracted with $100 \%$ ethanol in the ratio 1:10 at room temperature for $48 \mathrm{~h}$. The residue was re-extracted under the same condition until the extraction solvents became colorless. The obtained extract was filtered, air dried and percent recovery was calculated. The dried extract was stored at $4^{\circ} \mathrm{C}$ for further analysis.

\section{Chemicals}

2, 2 Diphenyl-1-1-picrylhydrazyl (DPPH), Quercetin, Thiobarbituric acid (TBA), Gallic acid, Phenazine Metho Sulfate (PMS), Reduced Nicotinamide Adenine Dinucleotide (NADH), FolinCiocalteu reagent and Sodium Nitro Prusside (SNP) of Himedia were used. All other chemicals and solvents used were of standard analytical grade.

\section{Physiochemical Analysis}

The powdered leaf and root parts were subjected to physicochemical analysis by the methods described by Indian Pharmacopoeia [2]. The various fractions of successive extracts were weighed and preliminary phytochemical screening tests were carried out on the ethanolic extract and on the powdered specimens using Standard procedures to identify the constituents as described by Sofowara (Sofowara, A., 1993), Trease and Evans W.C., 1989) and Harbone (Harborne, J.B., 1973).

\section{High Performance Thin Layer Chromatography}

HPTLC was performed on aluminum packed silica gel 60F254 HPTLC plates (Merck). Themobile phase was acetone - alcohol (1:1) for Ethyl alcohol extracts of both the samples. Samples were applied to the plates as sharp bands by means of Camag Linomat IV samples applicator. After drying the spots in a current of air the plats were placed in one trough of Camag twin trough glass chamber. The mobile phase was poured into the chamber left to equilibrate for $30 \mathrm{~min}$. the plate was then developed until the solvent front had traveled a distance of $7 \mathrm{~cm}$ above the position of sample application. The plate was removed from the chamber and dried in acurrent of air. Detection was performed with a Camag TLC Scanner. 
Chromatographic Condition: Stationary Phase: HPTLC Aluminum plate percolated with silica gel 60F254.Solvent system: Acetone - Alcohol (1:1), Separation Technique : Ascending, Migration distance : 70mm,Detection : UV, Wave length : 270nm.

\section{Determining the antioxidant status of Mukia leaves}

The sample for the estimation of total phenolic content and total flavonoid content was prepared in the following manner. A precisely weighed amount $(10 \mathrm{~g})$ of leaves were extracted with $80 \%$ ethanol $\left(3 \times 100 \mathrm{ml}, 40^{\circ} \mathrm{C}, 24 \mathrm{~h}\right)$ cooled to room temperature and centrifuged at $4500 \mathrm{rpm}$ for 15 minutes. The supernatants are quantitatively recovered and made up to the mark in $100 \mathrm{ml}$ standard flask for analysis. The quantitative estimation was being carried out for replication through standard spectrophotometric methods according to methods of Ranganna (1979).

\section{Results and Discussion}

\subsection{Physiochemical Analysis}

Organoleptic analysis of Mukia leaves revealed it as the greenish, smell less, slightly bitter powder. Total ash content, water-soluble ash, acid-insoluble ash, sulphated ash values of dried Mukia leaves were found to be $10.57 \%, 9.13 \%, 21.66 \%$ respectively. The solubility values were found to be $8.64 \%$ in alcohol and $8.65 \%$ in water. Successive studies on the extractive values of dried and fresh leaves of Mukia maderaspatana are given in the following table and it was found that maximum extractive value was obtained with ethanol for both dehydrated $(7.217 \%)$ and fresh leaves $(6.731 \%)$.

Table 1: Physicochemical analysis and extractive values (Percentage) of dehydrated Mukia leaves

\begin{tabular}{|l|l|l|}
\hline $\begin{array}{c}\text { Sl. } \\
\text { No }\end{array}$ & \multicolumn{1}{|c|}{ Parameters } & $\begin{array}{c}\text { Result/ Percentage } \\
\text { of dried leaf powder }\end{array}$ \\
\hline $\mathbf{1}$ & Organoleptic characteristics & \\
& a. Appearance & Powder \\
& b. Color & Greenish \\
& c. Smell & No smell \\
& d. Taste & Slightly Bitter \\
\hline \multirow{2}{*}{$\mathbf{2}$} & Total Ash value & \\
& Acid insoluble ash & 10.57 \\
& Sulphated ash & 9.13 \\
\hline $\mathbf{3}$ & Solubility values & 21.66 \\
& Alcohol & 8.64 \\
& Water & 8.65 \\
\hline
\end{tabular}


Table 2: Extractive value of dried and fresh Mukia leaves

\begin{tabular}{|r|r|rr|}
\hline $\begin{array}{c}\text { Type of } \\
\text { Extract }\end{array}$ & $\begin{array}{c}\text { Extractive value of dried leaves of } \\
\text { Mukia (\%) }\end{array}$ & $\begin{array}{c}\text { Extractive values of fresh leaves of } \\
\text { Mukia (\%) }\end{array}$ \\
\hline Ethanol & $\mathbf{7 . 2 1 7}$ & $\mathbf{6 . 7 3 1}$ \\
\hline Benzene & 2.020 & 2.130 \\
\hline $\begin{array}{r}\text { Chloroform } \\
\text { Petroleum } \\
\text { ether }\end{array}$ & 3.231 & 2.110 \\
\hline Methanol & 2.016 & 3.082 \\
\hline Water & & 0.231 & 710 \\
\hline
\end{tabular}

\subsection{Phytochemical Screening of Fresh and Dried Ethanolic Extract of Mukia Maderaspatana}

The qualitative analysis of the ethanolic extracts from the leaf sample of Mukia maderaspatana showed the presence of phytochemical constituents such as tannins, saponin, flavonoids, terpenoids and alkaloids. Whereas the phytochemical constituents like steroids, oils, gums were absent (Table. 3).

Table 3: Phytochemical analysis of ethanolic extract of Mukia leaves

\begin{tabular}{|l|l|l|l|}
\hline S.No & Phytochemicals & Fresh Mukia & Dehydrated Mukia \\
\hline 1 & Flavonoids & + & + \\
\hline 2 & Steroids & - & - \\
\hline 3 & Phenols & + & + \\
\hline 4 & Tannins & + & + \\
\hline 5 & Saponins & + & + \\
\hline 6 & Alkaloids & + & + \\
\hline 7 & Carbohydrates & + & + \\
\hline 8 & Proteins & + & + \\
\hline 9 & Fixed oils \& fats & - & - \\
\hline 10 & $\begin{array}{l}\text { Gum\& } \\
\text { Mucilage }\end{array}$ & - & - \\
\hline 11 & Glycosides & + & + \\
\hline
\end{tabular}

Constituents: $+=$ Present: $-=$ Absent

\subsection{Evaluation of active biomolecules of Mukia leaves}

HPTLC finger print profile helps for the identification of active biological compounds and further isolation and characterization of various bands are to be carried out. Both the leaf samples showed the Rf value 0.31 , which is similar to that of $\beta$-sitosterol standard and RF 0.54 showed the presence of quercetin. The fresh leaves of Mukia showed the $\mathrm{Rf}$ value 0.21 which is similar to that of columbin which was not present in dehydrated leaves, whereas the dehydrated leaves contain one additional band of $\mathrm{Rf}$ value 0.74 which seems to be an unknown compound. Standard HPTLC finger print profiles of leaf of $M$. maderaspatana with similar Rf values to that of previous works reveal the possibility of presence of $\boldsymbol{\beta}$-sitosterol, quercetin and columbin in M. maderaspatana. (T.S.Dhanaraj and M. Jegadeesan.2011) ( Figure.2, Graph.1,2 and Table.4 ). 


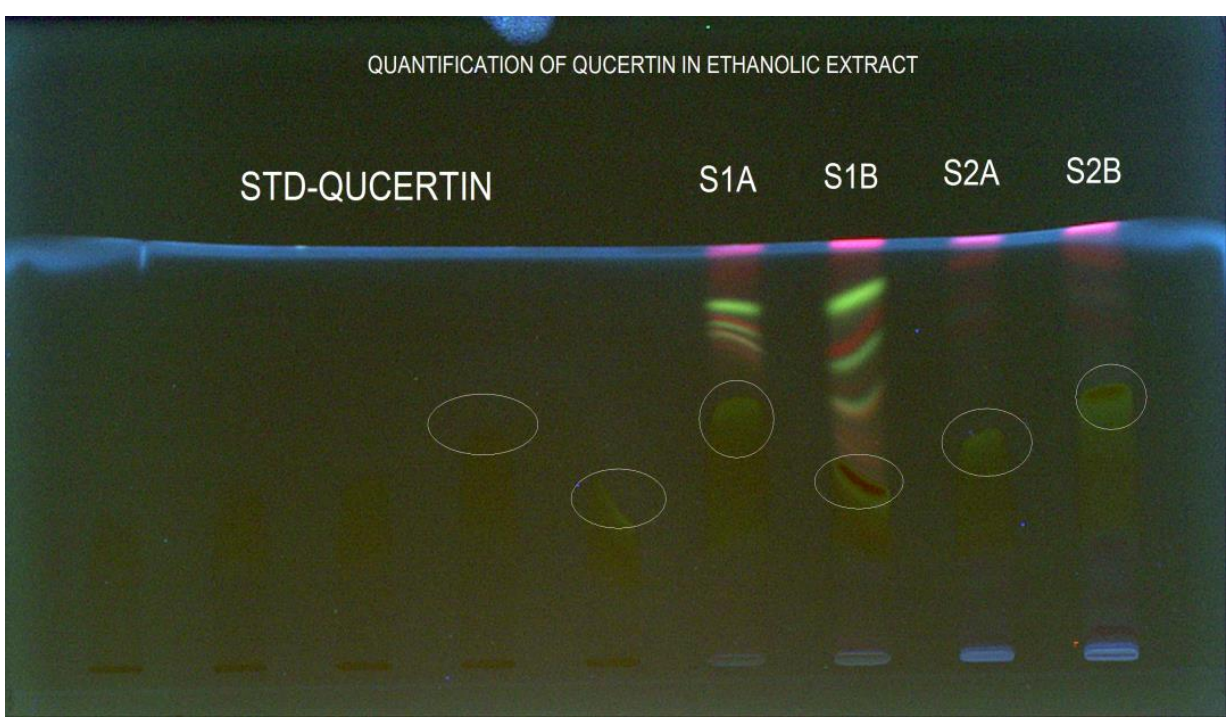

Figure 2: Detection of Quercetin in Mukia leaf extracts at $366 \mathrm{~nm}$ by HPTLC technique under UV light

S1A, S1b-Fresh Mukia leaves

S1b, S2b-Cabinet dried Mukia leaves, circles -indicate the presence of quercetin

Track 3, ID: STD_QUCRTIN $100 \mathrm{ppm}$

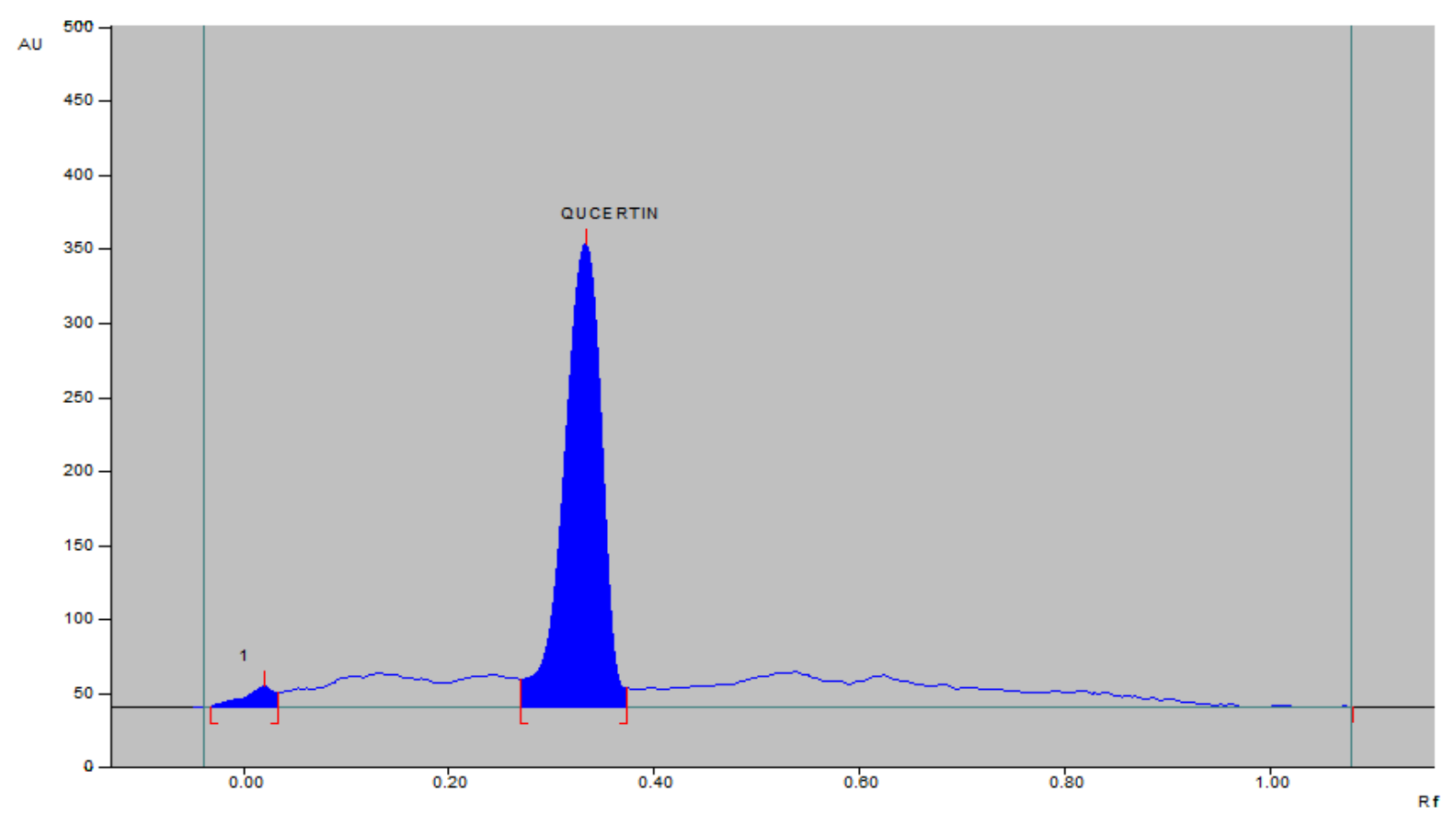

Graph 1: Std Quercetin 
Track 5, ID: S2

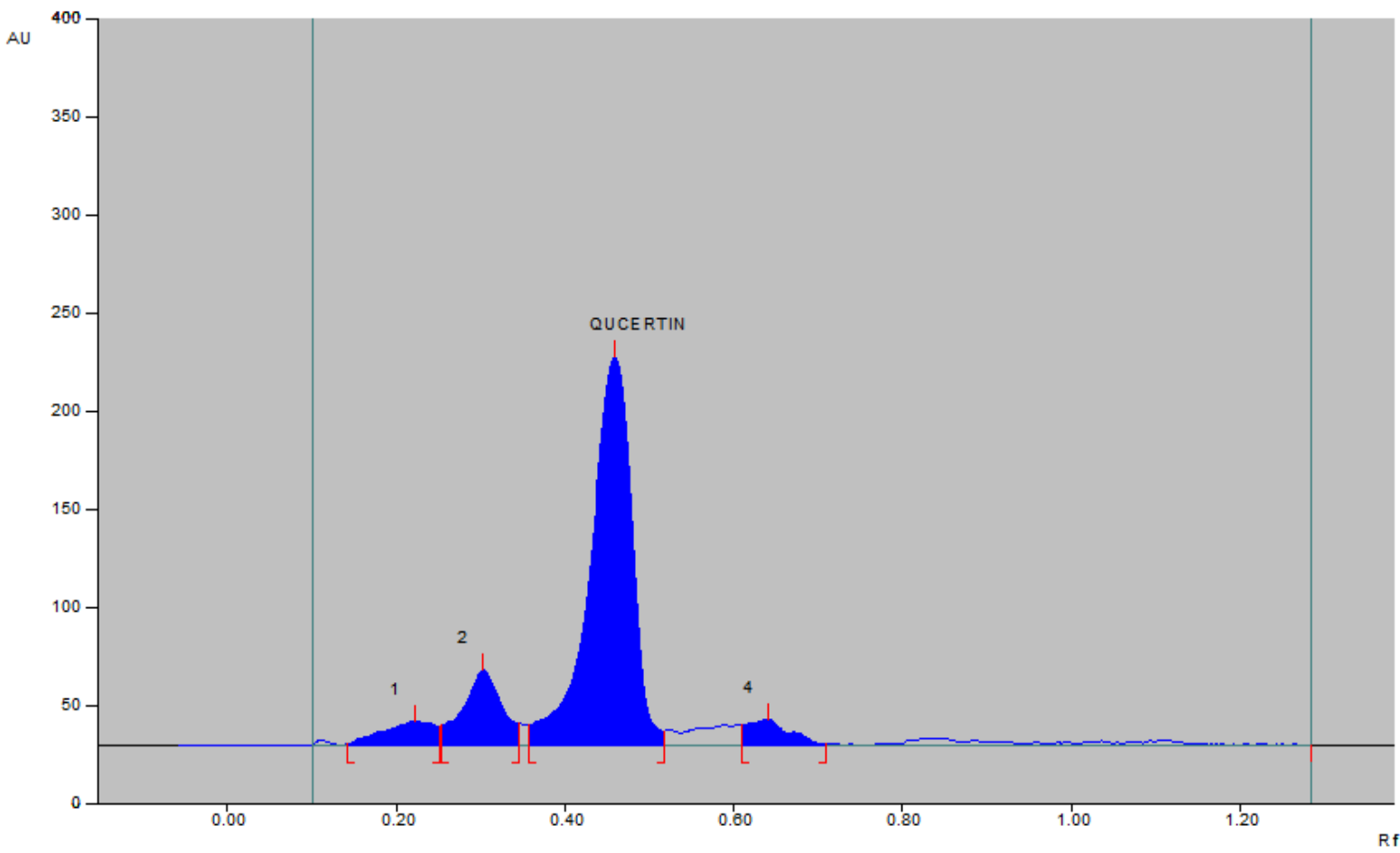

Graph 2: HPTLC finger print of fresh Mukia leaves showing the presence of quercetin

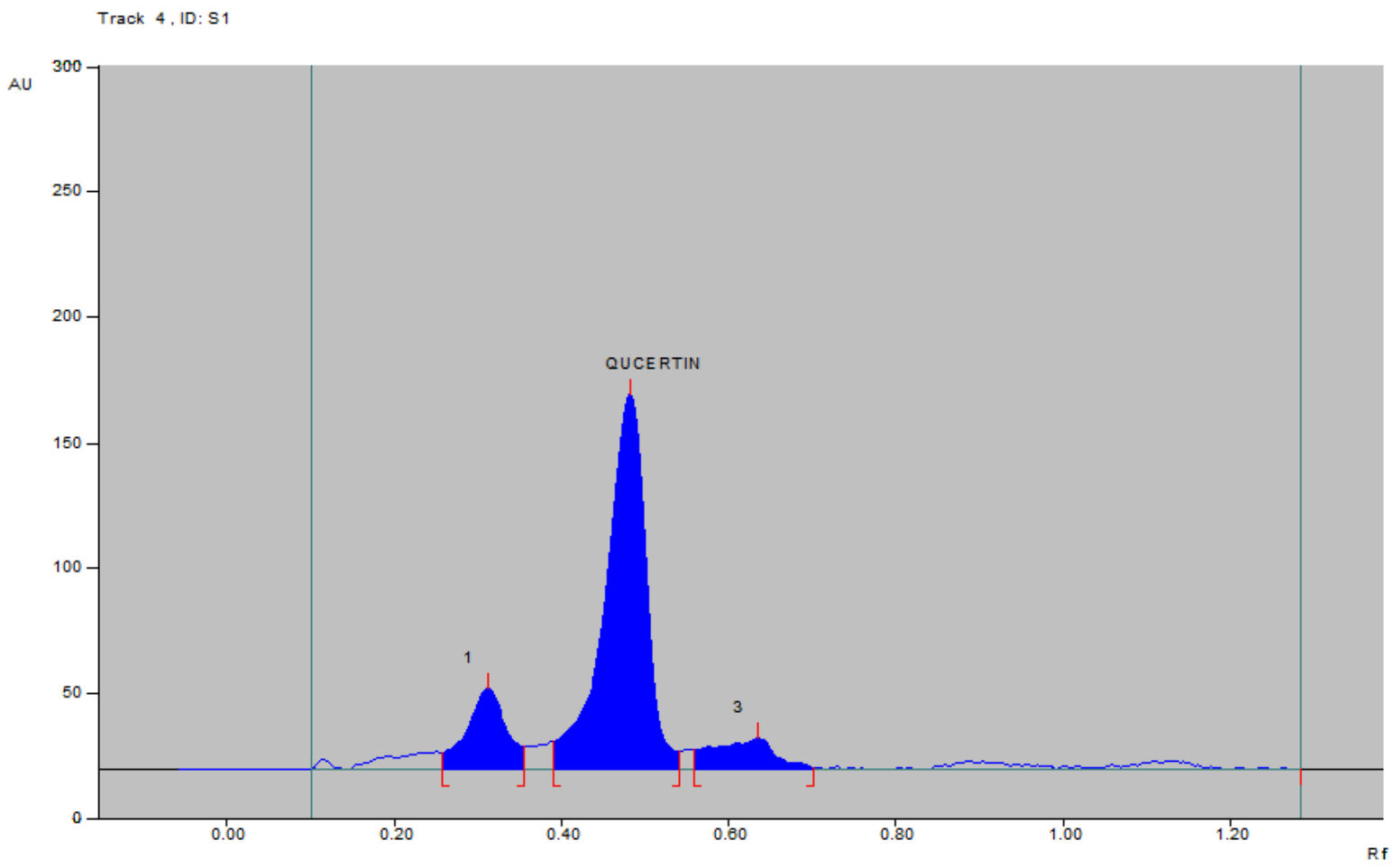

Graph 3: HPTLC finger print of cabinet dried Mukia leaves showing the presence of quercetin 
Table 4: HPTLC profile of Leaf extracts of of Mukia maderaspatana

\begin{tabular}{|c|c|c|c|c|c|c|}
\hline $\begin{array}{l}\text { S. } \\
\text { No }\end{array}$ & Sample & $\begin{array}{c}\text { Total No. of } \\
\text { spots }\end{array}$ & $\begin{array}{c}\text { No. of } \\
\text { major spots }\end{array}$ & $\begin{array}{c}\text { Retention } \\
\text { factor }\end{array}$ & $\begin{array}{l}\% \text { of } \\
\text { area }\end{array}$ & $\begin{array}{l}\% \text { of } \\
\text { yield }\end{array}$ \\
\hline \multirow{3}{*}{1} & \multirow{3}{*}{ Fresh Leaf } & \multirow{3}{*}{4} & \multirow{3}{*}{3} & 0.21 & 1916 & 18.85 \\
\hline & & & & 0.30 & 5984 & 58.86 \\
\hline & & & & 0.54 & 2985 & 34.45 \\
\hline \multirow[t]{3}{*}{2} & \multirow{3}{*}{$\begin{array}{l}\text { Dehydrated leaf } \\
\text { (cabinet dried at } 60^{\circ} \mathrm{C} \text { ) }\end{array}$} & \multirow{3}{*}{3} & \multirow{3}{*}{3} & 0.31 & 222.4 & 10.00 \\
\hline & & & & 0.55 & 2231.7 & 26.52 \\
\hline & & & & 0.74 & 1774.8 & 79.75 \\
\hline 3 & Std quercetin & 1 & 1 & 0.54 & 3034.2 & 74.15 \\
\hline
\end{tabular}

\subsection{Determining the Antioxidant Status of Mukia Leaves}

The amount of total phenolics and flavonoids present in fresh, sun dried \& dehydrated leaves were found to be as followed.

Table 5: Total phenolic Content of Mukia leaves

\begin{tabular}{|l|l|l|}
\hline S.No. & Sample & $\begin{array}{l}\text { Total phenolic content } \\
(\mathbf{m g} \text { GAE} / 100 g) \text { Mean } \pm \text { SD }\end{array}$ \\
\hline 1. & Fresh Mukia leaves & $281.32 \pm 1.08$ \\
\hline 2. & Sun dried Mukia leaves & $257.51 \pm 0.97$ \\
\hline 3. & Dehydrated Mukia leaves (cabinet dryer $\left.60^{\circ} \mathrm{C}\right)$ & $269.34 \pm 0.78$ \\
\hline
\end{tabular}

Table 6: Total flavonoid content of Mukia leaves

\begin{tabular}{|l|l|l|}
\hline S.No. & Sample & $\begin{array}{l}\text { Total Flavonoid content } \\
(\mathbf{m g} \text { QE/100g) Mean } \pm \text { SD }\end{array}$ \\
\hline 1. & Fresh Mukia leaves & $247.32 \pm 0.70$ \\
\hline 2. & Sun dried Mukia leaves & $239.51 \pm 0.73$ \\
\hline 3. & Dehydrated Mukia leaves (cabinet dryer at $\left.60^{\circ} \mathrm{C}\right)$ & $243.34 \pm 0.78$ \\
\hline
\end{tabular}

Table 7: Total antioxidant activity by DPPH Assay of Mukia leaves

\begin{tabular}{|l|l|l|}
\hline S.No & Sample & Antioxidative capacity \\
\hline 1. & Fresh Mukia leaves & $589 \pm 23$ \\
\hline 2. & Sun dried Mukia leaves & $487 \pm 15$ \\
\hline 3. & Dehydrated Mukia leaves (cabinet dryer $\left.60^{\circ} \mathrm{C}\right)$ & $543 \pm 46$ \\
\hline 4. & Quercetin (standard compound) & $360 \pm 71$ \\
\hline
\end{tabular}

Antioxidative capacity [ $\mu \mathrm{mol}$ Trolox $/ 100 \mathrm{~g}$ sample Mean \pm SD] of the dehydrated Mukia leaves and selected reference compounds by DPPH assay

For the determination of the antioxidative capacity the total antioxidant assay and DPPH assay was applied. The results showed that the cabinet dried Mukia leaves found to contain maximum phenolic as well as flavonoid content as compared with sun dried leaves and also displayed high antioxidative capacities as compared to quercetin standard compounds (Thabrew, etal., 1995). The total antioxidant activity of cabinet dried Mukia leaves extracts found to be more than sun dried 
leaves. Relatively high total antioxidant activity in the Mukia extract compared to standard showed a significant correlation with polyphenolic and flavonid contents (table III.ia,iia and iiia) suggesting the importance of polyphenolic's as potential antioxidant biomolecules. Dehydrated Mukia leaves with a high content of phenolic and flavonoid compounds and antioxidant activity could be used as a functional ingredient for cancer therapy.

\section{Conclusion}

In the current fast moving life which overrules the tradition, food habits and lifes style transformations are leading to various chronic diseases .In this context, the benefits of the underutilized leafy vegetable like Mukia madarasapatana can be exploited as a convenient potent source of functional food for poor people, who could also be motivated to cultivate such under utilized nutritive vegetable for their livelihood. Especially nowadays, the dehydrated vegetables act as the continuous source of energy, minerals and therapeutic phytochemicals. The current research explored the presence of Quercetin, the major antioxidant in dehydrated Mukia leaves in significant quantity which is currently being used as a potent anti tumour molecule in pharmaceutical industries.

\section{Acknowledgement}

The authors are grateful to ICAR-PHT for funding the research and SITRA, Coimbatore for providing the HPTLC analytical facilities.

\section{References}

[1] Oselebe H O, Nnamani C V, Okporie, E O. (2013). Ethano botanical Survey of underutilized crops and spices of some local communities in Nigeria: Potentials for improved nutrition, food security and poverty reduction. IOSR Journal of Pharmacy. 2013; 3: 21-28.

[2] Wichi H P. Enhanced tumour development by butylated hydroxyanisole (BHA) from the prospective of effect on fore stomach and oesophageal squamous epithelium. Food and Chemical Toxicology. 1988; 26: 717-723.

[3] Ramarathnam, N.; Ochi, H.; Takeuchi, M. Antioxidant defense system in vegetable extracts. In Natural Antioxidants: Chemistry, Health Effects, and Applications; Shahidi, F.,Ed.; AOCS Press: Champaign, IL, 1997; 76-87.

[4] AN Kesari, RK Gupta, G Watal. Hypoglycemic effects of Murraya koenigii on normal and alloxandiabetic rabbits . Journal of Ethno pharmacology 97 (2), 247-251.

[5] Khanna. A.K., Rizvi, F., and Chander, R. 2002. Lipid lowering activity of Phylanthus niniri in hyperlipemic rats. J. Ethnopharmacol. 82, 19-22.

[6] Thabrew MI, Hughes RD, McFarlane IG. Antioxidant activity of Osbeckia aspera. Phytother Res.1998; 12:288-290.

[7] Kirtikar KR, Basu BD. Indian Medicinal Plants.Vol. 3. $2^{\text {nd }}$ ed. In: Kirtikar KR, Basu BD (eds). Dehra Dun, India: 201 Singh et al. International Journal of Phytomedicine 2 2010.197-209

[8] Chopra RN, Nayar SL, Chopra IC. Glossary of Indian Medicinal Plants. New Delhi, CSIR, 1986, 29.

[9] Kunkel G. Plants for human consumption. J Agric Food Chem 59(10): Koeltz Scientific Books, Koenigstein Kuroyanagi M, Yoshida K, 1984. 5665 - 5670.

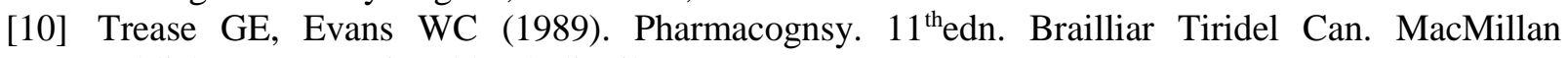
publishers. International book distributors, 1987; 2061-2062. 
[11] Sofowora A. Medicinal Plants and Traditional Medicinal in Africa. 2nd Ed. Sunshine House, Ibadan, Nigeria: Spectrum Books Ltd; 1993. Screening Plants for Bioactive Agents. $134-156$.

[12] Harborne, J.B., 1973.Phytochemical Methods. London. Chapman and Hall Ltd.49-188.

[13] T.S. Dhanaraj and M. Jegadeesan. Physico-chemical and HPTLC studies on leaf and root of Mukiamaderaspatana (L.) M. Roemer. J. Chem. Pharm. Res., 2011.3 (3):375-380.

[14] Kalaskar et al ,2012. Studies on drying and dehydration of fenugreek leaves. International journal of processing and post harvest technology.Vol.3.15-17.

\footnotetext{
*Corresponding author.

E-mail address: amirtham_d@ yahoo.com
} 